\title{
Amino-terminal sequencing of the ovine milk fat globule membrane protein butyrophilin
}

\author{
Lucile Montagne ${ }^{\mathrm{a}}$, Jean-Michel Girardet ${ }^{\mathrm{b} *}$, Gérard Humbert ${ }^{\mathrm{b}}$ \\ ${ }^{\text {a }}$ Laboratoire du jeune ruminant, Inra, 65, rue de Saint-Brieuc, 35042 Rennes cedex, France \\ ${ }^{b}$ Laboratoire des biosciences de l'aliment, unité associée à l'Inra, \\ université Henri-Poincaré-Nancy-1, 54506 Vandœuvre-lès-Nancy cedex, France
}

(Received 30 April 1998; accepted 30 July 1998)

\begin{abstract}
Butyrophilin, a transmembrane protein of the milk fat globule membrane, was identified in cows' and ewes' milk by amino acid $\mathrm{N}$-terminal sequencing. The $\mathrm{N}$-terminal part of ovine butyrophilin was identical to that of the human protein. A butyrophilin-type protein with an $M_{\mathrm{r}}$ of 62000 was also found in equimolar proportions with butyrophilin in ovine milk. This smaller $M_{\mathrm{r}}$ form was probably generated by plasmin-mediated hydrolysis during or following lactation in the epithelial cells of the mammary gland and corresponded to a smaller $M_{\mathrm{r}}$ form of butyrophilin lacking the C-terminal region. (C) Inra/Elsevier, Paris
\end{abstract}

butyrophilin / milk fat globule membrane / ovine milk

Résumé - Séquence $\mathbf{N}$-terminale de la butyrophiline de la membrane des globules gras du lait de brebis. La butyrophiline, une protéine transmembranaire de la membrane des globules gras, a été identifiée dans les laits de vache et de brebis par séquençage de son extrémité $\mathrm{N}$-terminale. Les 14 résidus d'acides aminés $\mathrm{N}$-terminaux de la butyrophiline ovine sont identiques à ceux de la protéine humaine. De plus, une protéine de type butyrophiline et de poids moléculaire 62000 a été mise en évidence en proportion équimolaire avec la butyrophiline dans le lait ovin. Cette forme ayant un poids moléculaire plus petit serait produit par action de la plasmine associée aux membranes dans les cellules épithéliales de la glande mammaire au cours ou après la lactation et correspondrait à de la butyrophiline dont la partie C-terminale aurait été tronquée. (C) Inra/Elsevier, Paris

butyrophiline / membrane des globules gras / lait de brebis

* Correspondence and reprints. Jean-Michel.Girardet@scbiol.u-nancy.fr 


\section{INTRODUCTION}

Butyrophilin is an acidic glycoprotein with apparent $M_{\mathrm{r}}$ of 67000 associated with the membrane surrounding fat droplets in milk. It constitutes $40 \%$ of the total milk fat globule membrane (MFGM) protein (for review, see [14]). This protein may function in the process of milk secretion because it is specifically expressed on the apical surface of mammary secretory cells during lactation. Butyrophilin and xanthine oxidase (EC 1.2.3.22) may form a supramolecular complex with low $M_{\mathrm{r}}$ guanosine triphosphate (GTP)-binding proteins in the membrane $[3,8,15]$.

Butyrophilin has been detected in several species, including cow, ewe, goat, pig, human, rat, guinea pig [4] and mouse [8]. cDNA clones encoding bovine, murine and human butyrophilin were isolated and the primary structures of the three proteins deduced from the DNA sequences $[8,9,17$, 20]. The $19 \mathrm{~N}$-terminal amino acid residues of guinea pig butyrophilin were sequenced [16]. It appears that butyrophilin is composed of two extracellular immunoglobulin superfamily domains (immunoglobulin $\mathrm{V}$ [ $\mathrm{IgV}]$ - and immunoglobulin $\mathrm{Cl}$ [ $\mathrm{IgCl} 1$-type domains), a transmembrane domain and an intracellular domain homologous to the B30.2 domain of several intracellular proteins $[5,6]$, including the ret finger protein (RFP), the $52000 M_{\mathrm{r}}$ nuclear antigen A of Sjögren's syndrome (SS-A/Ro) and Xenopus nuclear factor $7[9,20,21]$. The $\mathrm{N}$-terminal extracellular domain shares similarities to myelin/oligodendrocyte glycoprotein (MOG) and to the major histocompatibility complex chicken B blood group system (B-G) proteins $[11,21]$. This particular structure of butyrophilin suggests a cell surface receptor function [20].

Butyrophilin has a potential function in lactation and a hypothetical role in autoimmune diseases such as human multiple sclerosis. In fact, the $\operatorname{IgV~N}$-terminal region of MOG is able to induce acute demyelinat- ing experimental autoimmune encephalomyelitis in rats [1]. Moreover, significant correlations were found between liquid cow milk, cream or butter consumption and the prevalence of multiple sclerosis [12]. The bovine and ovine species are of economical and biotechnological interest. Ewes' milk has a higher fat content $\left(70 \mathrm{~g} \cdot \mathrm{L}^{-1}\right)$ than cows' milk ( $\left.38 \mathrm{~g} \cdot \mathrm{L}^{-1}\right)$, related to a high level of expression of MFGM proteins. In this study, ovine butyrophilin was separated by electrophoresis, electrotransferred onto a membrane and then characterized by amino acid $\mathrm{N}$-terminal sequencing. Two forms of butyrophilin with $M_{\mathrm{r}}$ s close to 66000 and 62000 , respectively, were found in equimolar proportions in ovine milk.

\section{MATERIALS AND METHODS}

\subsection{Extraction of MFGM}

Cream was separated from $5 \mathrm{~L}$ of bovine or ovine milk by centrifugation at $3000 \mathrm{~g}$ and $30^{\circ} \mathrm{C}$ for $15 \mathrm{~min}$. The cream was washed three times in five volumes of $100 \mathrm{mmol} \cdot \mathrm{L}^{-1}$ Tris buffer, $\mathrm{pH} 7.2$, containing $250 \mathrm{mmol} \cdot \mathrm{L}^{-1}$ sucrose, $100 \mathrm{mmol} \cdot \mathrm{L}^{-1} \mathrm{MgCl}_{2}, 0.24$ inhibiting $\mathrm{U} \cdot \mathrm{mL}^{-1}$ trypsin inhibitor from egg white (Serva Feinbiochemica, D-69042 Heidelberg 1, Germany) and $5 \mathrm{mmol} \cdot \mathrm{L}^{-1} \varepsilon$-aminocaproic acid. One volume of cream suspended in two volumes of Tris buffer were shaken on a laboratory shaker until butter formed. The mixture was then warmed to $40^{\circ} \mathrm{C}$ to release membrane trapped by butter granules and centrifuged at $100000 \mathrm{~g}$ at $4{ }^{\circ} \mathrm{C}$ for $1 \mathrm{~h}$. The MFGM pellet was finally freezedried [7].

\subsection{Isolation and sequencing of butyrophilin}

The MFGM ( $\left.2 \mathrm{mg} \cdot \mathrm{mL}^{-1}\right)$ from bovine or ovine milk was solubilized in a $55 \mathrm{mmol} \cdot \mathrm{L}^{-1}$ Tris buffer at $\mathrm{pH} 6.8$ containing $23 \mathrm{mg} \cdot \mathrm{mL}^{-1}$ sodium dodecyl sulphate (SDS) and $13.3 \%$ (v/v) 2-mercapthoethanol, and boiled for $3 \mathrm{~min}$. The MFGM proteins were then separated by SDS-polyacrylamide gel electrophoresis (SDS-PAGE, [10]) and electrophoretically transferred to polyvinylidene difluoride (PVDF) membranes. The trans- 
fer buffer was composed of $10 \mathrm{mmol} \cdot \mathrm{L}^{-1} \mathrm{CAPS}$ (3-[cyclohexylamino]-1-propanesulfonic acid; Sigma Chemical Co., Saint-Louis, MO, USA) at $\mathrm{pH} 11$, containing $10 \%(\mathrm{v} / \mathrm{v})$ methanol. Nterminal sequences of the bound proteins were carried out by Edman degradation using a 476A sequencer from Applied Biosystems (Foster City, CA, USA).

\section{RESULTS AND DISCUSSION}

On the SDS-PAGE profile of bovine MFGM proteins (figure 1), the principal band was located at an apparent $M_{\mathrm{r}}$ of 66000 and corresponded to butyrophilin as demonstrated by $\mathrm{N}$-terminal amino acid residue sequencing (figure 2). A minor component with apparent $M_{\mathrm{r}} 62000$ was associated with bovine butyrophilin and was hardly detectable on the SDS-PAGE profile. Bovine butyrophilin represented $38 \%$ of the total MFGM proteins (determined by densitometry).

The ovine MFGM contained also a $66000 M_{\mathrm{r}}$ butyrophilin-type protein. Sequence alignments showed a strong identity between the two species. The N-terminal region presented only one mutation site, a proline residue instead of a glutamine residue at position 9 (figure 2). Recently, in the case of bovine butyrophilin, both glutamine and asparagine residues were detected at position 9 [2], due to allelic polymorphism. The $\mathrm{N}$-terminal region of the ovine butyrophilin was $100 \%$ identical to that of human butyrophilin. The whole human protein sequence is $84 \%$ identical to the bovine sequence [20]. Both proteins share the same number of residues and contain no gaps in their alignment. Structural domains between bovine butyrophilin and proteins of the other species (human, guinea pig, mouse and ewe, most likely) are similar, which suggests a conserved function between species.

In our study, an additional $62000 M_{\mathrm{r}}$ butyrophilin-type protein was identified in ovine MFGM (figure 1). The N-terminal

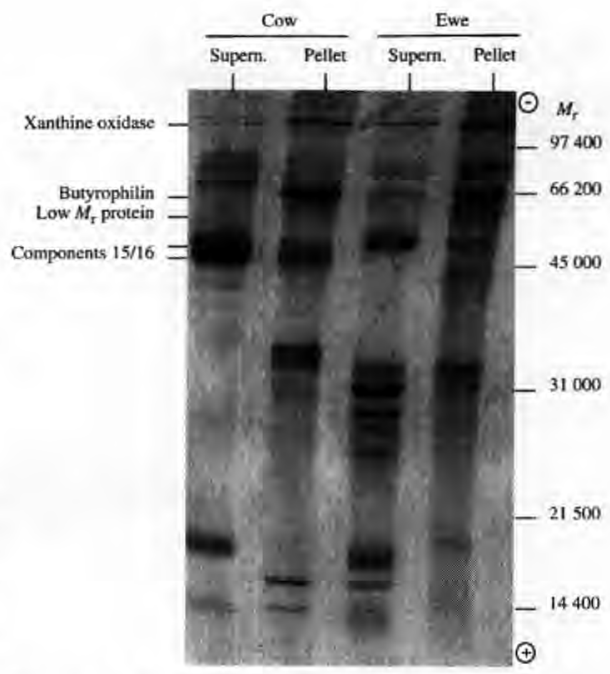

Figure 1. Electrophoresis $(15 \%[\mathrm{w} / \mathrm{v}]$ polyacrylamide, $0.1 \%[\mathrm{w} / \mathrm{v}]$ sodium dodecyl sulphate, $\mathrm{pH}$ 8.8) of supernatants (Supern.) and pellets (Pellet) after ultracentrifugation of the bovine and ovine milk fat globule membranes.

Figure 1. Électrophorèse (polyacrylamide à $15 \%$ $(\mathrm{p} / \mathrm{v})$, sulfate de dodécyle et de sodium à $0,1 \%$ (p/v), $\mathrm{pH} 8,8$ ) des surnageants (Supern.) et culots (Pellet) après ultracentrifugation des membranes des globules gras de laits bovin et ovin.

region of this low $M_{\mathrm{r}}$ butyrophilin-type protein was $100 \%$ identical to that of ovine butyrophilin. The 66000 and $62000 M_{\mathrm{r}}$ proteins represented 13 and $13.6 \%$ of the total membrane proteins, respectively. In another study [4], the SDS-PAGE profiles of bovine and ovine MFGM were similar and the low $M_{r}$ butyrophilin-type protein of the ovine MFGM was a minor component. Other minor fragments of bovine butyrophilin with smaller $M_{\mathrm{r}}$ are also found in the MFGM [2]. Butyrophilin from human MFGM migrates by SDS-PAGE as a doublet of about $M_{\mathrm{r}} 65000$ and 60000 [20].

Smaller $M_{\mathrm{r}}$ forms of butyrophilin are probably proteolytic fragments either produced in situ by MFGM-associated plasmin or during isolation of MFGM $[2,13]$. However, we did include inhibitors of plasmin 
Present work

Low $M_{\mathrm{r}}$ butyrophilin-type

protein of ovine MFGM

Butyrophilin of ovine MFGM

Butyrophilin of bovine MFGM
APFD VIGPPE-

APFD VIGPPEPILA-

APFD VIGPQE-

Previous studies

Bovine butyrophilin [9] $\underbrace{1}_{[2]} \frac{11}{21}$

Human butyrophilin [20]

Mouse butyrophilin [8]

Mouse butyrophilin [17]
31

41

.APFD VIGPQEPILA VVGED.AELPC-

$\stackrel{\mathrm{Q}}{\mathrm{N}}$

APFD VIGPPEPILA VVGED. AELPC-

Guinea pig butyrophilin [16]

. RFD VIGPTEPVLA AVGGD.A-

Figure 2. N-terminal primary structures of the bovine and ovine butyrophilins and of the ovine low $M_{\mathrm{r}}$ butyrophilin-type protein compared to those of butyrophilins of various species reported in the literature. Amino acid residues different to those of bovine butyrophilin are in bold-face type.

Figure 2. Structures primaires $\mathrm{N}$-terminales des butyrophilines bovine, ovine et de la protéine ovine de faible poids moléculaire de type butyrophiline comparées aux régions $\mathrm{N}$-terminales des butyrophilines de diverses espèces rapportées dans la littérature. Les résidus d'acides aminés différents de ceux de la butyrophiline bovine sont en caractères gras.

activity during the MFGM extraction (inhibitor from egg white and $\varepsilon$-aminocaproic acid). Proteolysis could occur earlier, i.e., during or following lactation, as in the case of proteose peptones generated by plasmin activity on $\beta$-casein in the epithelial cells of the mammary gland (for review, see [18]), or C-terminal fragment of component PP3 [19]. Plasmin activity might be greater in ewes' milk compared with cows' milk due to an elevated activation of the plasminogen associated with ovine MFGM.

We cannot exclude the possibility that other butyrophilin-like proteins are associ- ated with the MFGM. In humans, two genes (BT2, BT3 or B7c) which share similarities with the canonical structure of butyrophilin have been found [15]. These genes are localized in the major histocompatibility complex region close to the butyrophilin gene. Nevertheless, putative products of these genes share only $50 \%$ identity with the amino acid sequence of butyrophilin.

Further investigations will be carried out in order to understand why more of the low $M_{\mathrm{r}}$ form of butyrophilin is generated in ovine milk compared with bovine milk, 
either by proteolysis of the $66000 M_{\mathrm{r}}$ form of butyrophilin, or by expression of a BT gene.

\section{ACKNOWLEDGEMENTS}

We thank J. Henry, laboratoire de biochimie, faculté de médecine, Limoges, and F. Saulnier, service commun de séquences des protéines, université Henri-Poincaré, for good advice.

\section{REFERENCES}

[1] Adelmann M., Wood J., Benzel P., Fiori H., Lassmann H., Matthieu J.M., Gardinier M.V., Dornmair $\mathrm{K}_{\text {, }}$ Linington $\mathrm{C}$., The $\mathrm{N}$-terminal domain of the myelin oligodendrocyte glycoprotein (MOG) induces acute demyelinating experimental autoimmune encephalomyelitis in the Lewis rat, J. Neuroimmunol. 63 (1995) 17-27.

[2] Banghart L.R., Chamberlain C.W., Velarde J., Korobko I.V., Ogg S.L., Jack L.J.W., Vakharia V.N., Mather I.H., Butyrophilin is expressed in mammary epithelial cells from a single-sized messenger RNA as a type I membrane glycoprotein, J. Biol. Chem. 273 (1998) 4171-4179.

[3] Ghosal D., Ankrapp D., Keenan T.W., Low molecular mass GTP binding proteins are secreted from mammary epithelial cells in association with lipid globules, Biochim. Biophys. Acta 1168 (1993) 299-306.

[4] Heid H.W., Winter S., Bruder G., Keenan T.W., Jarasch E.D., Butyrophilin, an apical plasma membrane-associated glycoprotein characteristic of lactating mammary glands of diverse species, Biochim. Biophys. Acta 728 (1983) 228-238.

[5] Henry J., Ribouchon M.T., Depetris D., Mattei, M.G., Offer C., Tazi- Ahnini R., Pontarotti P., Cloning, structural analysis and mapping of the B30 and B7 multigenic families to the major histocompatibility complex (MHC) and other chromosomal regions, Immunogenetics 46 (1997) 383-395.

[6] Henry J,, Ribouchon M.T., Offer C., Pontarotti P., B30.2 like domain proteins: a growing family, Biochem. Biophys. Res. Commun. 235 (1997) 162-165.

[7] Imam A., Laurence J.R., Neville A.M., Isolation and characterisation of a major glycoprotein from milk-fat-globule membrane of human breast milk, Biochem. J. 193 (1981) 47-54.

[8] Ishii T., Aoki N., Noda A., Adachi T., Nakamura R., Matsuda T., Carboxi-terminal cytoplasmic domain of mouse butyrophilin specifically associated with a $150-\mathrm{kDa}$ protein of mammary epithelial cells and milk fat globule membrane, Biochim. Biophys. Acta 1245 (1995) 285-292.

[9] Jack L.J.W., Mather L.H., Cloning and analysis of cDNA encoding bovine butyrophilin, an apical glycoprotein expressed in mammary tissue and secreted in association with the milk-fat globule membrane during lactation, J. Biol. Chem. 265 (1990) 14481-14486.

[10] Laemmli U.K., Favre M., Maturation of the head of bacteriophage T4. I. DNA packaging events, J. Mol. Biol. 80 (1973) 575-599.

[11] Linsley P.S., Peach R., Gladstone P., Bajortah J, Extending the B7 (CD80) gene family, Protein Sci. 3 (1994) 1341-1343.

[12] Malosse D., Perron H., Sasco A., Seigneurin J.M., Correlation between milk and dairy product consumption and multiple sclerosis prevalence: a worldwide study, Neuroepidemiology 11 (1992) 304-312.

[13] Mather I.H., Proteins of the milk-fat-globulemembrane as markers of mammary epithelial cells and apical plasma membrane, in: Neville M.C., Daniel C.W. (Eds.), The Mammary Gland: Development, Regulation and Function, Plenum Publication Co., New York, 1987, pp. 217-267.

[14] Mather I.H., Jack L.J.W., A review of the molecular and cellular biology of butyrophilin, the major protein of bovine milk fat globule membrane, J. Dairy Sci. 76 (1993) 3832-3850.

[15] Mondy B.L., Keenan T.W., Butyrophilin and xanthine oxidase occur in constant molar proportions in milk lipid globule membrane but vary in amount with breed and stage of lactation, Protoplasma 177 (1993) 32-36.

[16] Neira L.M., Mather I.H., Biochemical and immunological comparison of bovine butyrophilin with a butyrophilin-like glycoprotein in guinea pig milk-fat-globule membrane, Protoplasma 159 (1990) 168-178.

[17] Ogg S.L., Komaragiri M.V.S., Mather I.H., Structural organization and mammary-specific expression of the butyrophilin gene, Mamm. Genome 7 (1996) 900-905.

[18] Pâquet D., Review; the proteose-peptone fraction of milk, Lait 69 (1989) 1-21.

[19] Sørensen E.S., Petersen T.E., Phosphorylation, glycosylation and amino acid sequence of component PP3 from the proteose peptone fraction of bovine milk, J, Dairy Sci. 60 (1993) 535-542.

[20] Taylor M.R., Peterson J.A., Ceriani R.L., Couto J.R., Cloning and sequence analysis of human butyrophilin reveals a potential receptor function, Biochim. Biophys. Acta 1306 (1996) 1-4.

[21] Vernet C., Boretto J., Mattei M.G., Takahashi M., Jack L.J.W., Mather I.H., Rouquier S., Pontarotti P., Evolutionary study of multigenic families mapping close to the human MHC class 1 region, J. Mol. Evol. 37 (1993) 600-612. 